\title{
EDITORIAL
}

\section{Learning from the sad, sorry saga at Stoke}

\author{
E Hey, P Fleming, J Sibert
}

Arch Dis Child 2002;86:1-3

\begin{abstract}
Editor's note
For three years, two UK paediatricians have had to contend with massive media criticism, much of it fed by a pressure group. The UK government, through its regional NHS office, set up an enquiry into one aspect of the complaints-related to the ethical committee approval process and the monitoring of clinical trials within their unit. Its report was critical but has been attacked, both by informed academics and researchers and in a House of Lords debate. In addition, their employer-an NHS trust hospital-set up three enquiry panels, to look at research issues, child protection issues and general disciplinary matters including financial probity. The third of these quickly found that the doctors concerned had behaved meticulously; the other panels met once and twice respectively before deciding there was "a case to answer". Immediately the doctors were suspended from work. The hospital then examined matters in detail under the auspices of the NHS complaints procedure. The allegations were found to be unsustainable, both doctors being cleared. During the prolonged process, they were barred from writing or speaking about their ordeal, so were unable to answer even the most outrageous allegations. In a press release announcing Prof Southall's reinstatement, the Trust chief executive stated: "No case to answer has been found in respect of professional misconduct or incompetence." The editorial below has been contributed by three paediatricians who have been close to the case. They point out many disturbing aspects. We hope it will never happen again, if only because such a prolonged process is likely to prove contrary to article 6.1 of the European Parliament's Human Rights Act.
\end{abstract}

H Marcovitch, Editor

S is it all over now, bar the shouting? Paediatricians in the UK have watched, with mixed emotions, the tale of how two senior colleagues at the North Staffordshire Hospital in Stoke on Trent were pilloried and abused by the media over an eight year period. ${ }^{1}$ Pilloried largely because they dared to become involved in the investigation of children thought to have suffered induced illness at the hands of those who cared for them. They have also watched in uneasy silence, uncertain of where the truth lay, and fearful that, by saying anything, they might make matters worse.

The local hospital Trust eventually suspended Dr Martin Samuels and Professor David Southall from duty, without warning, on 29 November 1999 because of "potentially serious, albeit unsubstantiated, allegations concerning child protection and research issues at the hospital" ${ }^{2}$ after media frenzy reached an all time high. Dr Samuels finally returned to work 20 months later after the Trust's "preliminary enquiry" found "no professional misconduct or incompetence". ${ }^{3}$ The Trust announced a similar conclusion in respect of Professor Southall in mid October ${ }^{4}$ after a suspension lasting 23 months-a suspension that the Trust always stressed was "not a disciplinary action."

Many will criticise the way this whole affair has been handled. The public has still not been offered any real explanation for the suspensions, or for the reinstatements. That is not the British way-and reasonably so. However, while people do not expect or want the details of every employment contract debated in public there are occasions, as here, where the outcome leaves nobody satisfied. Indeed, many will still feel that "there must have been something going on". Why else, they might ask, would the Government, the NHS Executive and the local Trust have spent so much time and effort investigating these things. To finally conclude that there was "no misconduct and no incompetence" must strain such individuals' credulity. Some will say it is a whitewash and a cover up. Others will say it was a witch hunt. No one is satisfied and no one is much the wiser. It has taken three years, cost the Trust $£ 750,000$, (US\$ $1.1 \mathrm{~m}$ ) and the NHS executive a further undisclosed sum. ${ }^{4}$

Some will wonder why so much attention was given to the repeated allegations of those who used the press and television ${ }^{5}$ to criticise the use of covert video surveillance in order to get overt evidence of suspected abuse, ${ }^{6}$ when these criticisms were backed by so little fact. Others will remain baffled as to why a Government investigation should have misjudged the quality of the neonatal research being conducted at Stoke so badly. ${ }^{7}$ Many will be surprised to learn that complaints from the families of children cared for at Stoke did not play a significant part in the process that led to suspension. Most will feel outrage that this whole investigation should have taken so long, and would challenge the judgement that the two doctors had to be barred from all clinical, teaching, research and administrative work while these inquiries took place. It is very hard to justify the severe stress this places on the families of those suspended. ${ }^{8}$

However, before we criticise those who were attempting to make the health service and the medical profession more publicly accountable for their actions, we need to ask how their employers came to believe they had to stop these two doctors working. It is easy to blame hospital and other NHS managers. It is easy to conclude, in retrospect, that management got it wrong locally, regionally and nationally. It is easy to drift into a culture of "us and them". Perhaps, however, we should first ask who advised management that, in the phrase used in the confidential internal Trust document, "serious concerns existed which warranted the without prejudice suspension of the two paediatricians pending a more detailed investigation under the Trust's employment procedures." We might also ask how the advisors came to be chosen, how the case material they were asked to review was selected, and how much work the advisors did before reaching this conclusion.

Unfortunately, because it is traditional to keep the working of such disciplinary inquiries confidential, neither the public nor the profession normally get to hear how such matters are handled. We are in the privileged position of having seen, between us, most of the relevant papers in this case while providing professional advice to the Medical Defense Union and the Medical Protection Society, and we have not been 


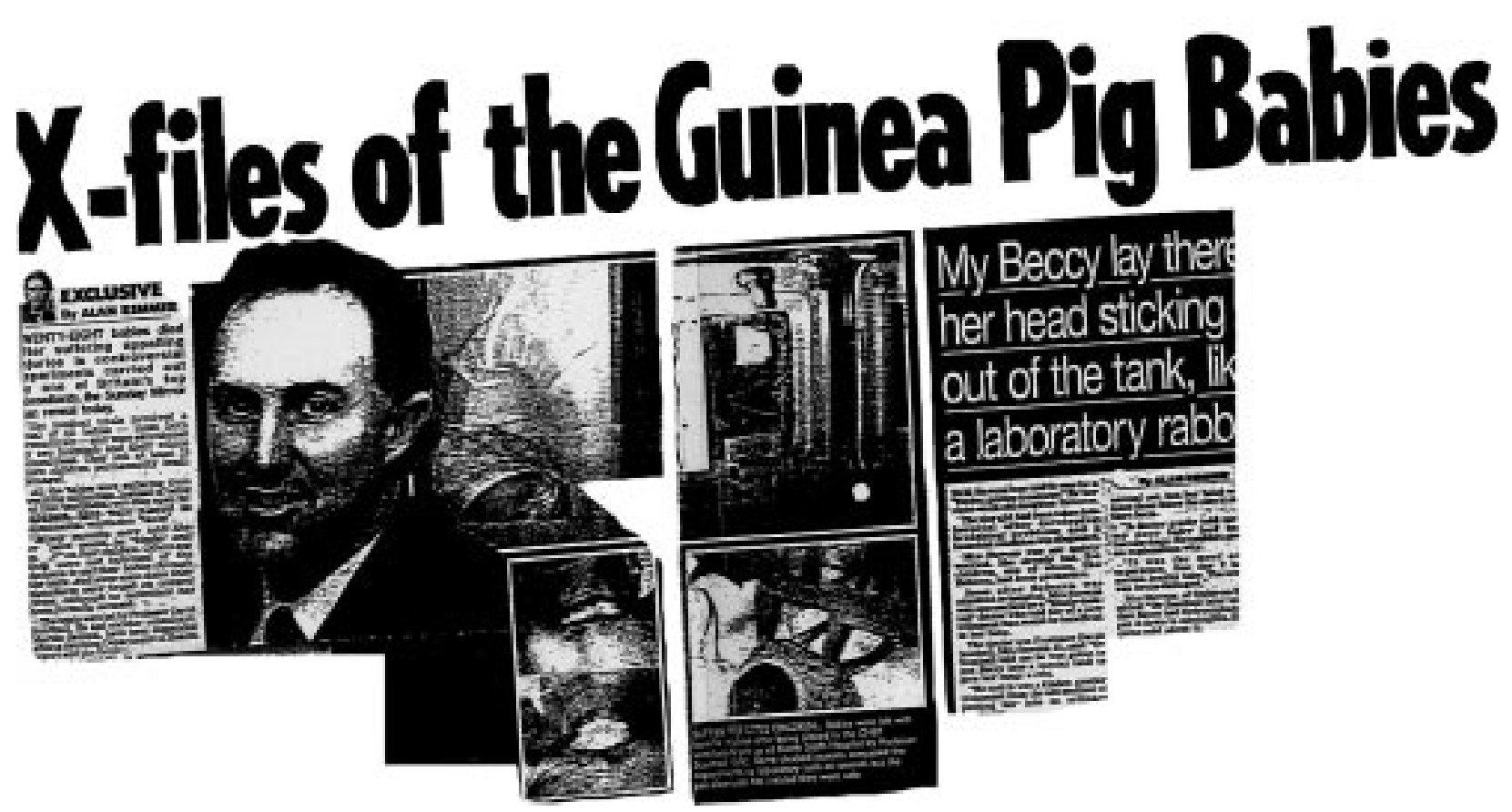

Figure 1 Two page press cutting from the Sunday Mirror, 9 July 2000. "Twenty eight babies died after suffering appalling injuries in controversial experiments carried out by one of Britain's top consultants."

reassured by what we have seen. Indeed, we believe that some members of our own College have contributed to the current debacle.

We think it very unlikely that pressure from those concerned at the way child abuse was being investigated ${ }^{9}$ would have triggered the original Government inquiry had allegations not started to circulate to the effect that babies in Stoke had died or been damaged because of "experimental treatment." Whether any doctor ever used such words we may never know. However, that was certainly what at least one family thought they had been told when they went seeking a second opinion. ${ }^{10}$ From then on references to the hospital's continuous negative extrathoracic pressure (CNEP) ventilation trial ${ }^{11}$ started to be couched in increasingly lurid and strident terms in the local and national press (see figure 1).

Further damage was done to the reputation of Professor Southall and Dr Samuels (and all the medical and nursing team in Stoke) by what is now acknowledged to have been a flawed Government report (the Griffiths report). ${ }^{12}$ The Trust is known to have completed its own internal review into the claims that trial consent forms were untraceable or forged in March 1999. Indeed, it even issued a press statement in September that year saying that "North Staffordshire Hospital holds consent forms signed by parents for every child in the CNEP study. The Hospital also holds copies of an information sheet signed by the parents for every child in the CNEP study."13 How the Government report, issued seven months later, came to include the damaging assertion that "report forms could not be found" has still not been explained..$^{12}$ The Government says that it still "has difficulty in understanding" why this information "was not made available to the panel" it had appointed. We have similar difficulty. The medically qualified civil servants who drafted that report remain mute.

However, our greatest concern relates to the confidential advice the Trust were given by external paediatric advisors in October and November 1999. Our College is said to have been asked to nominate one advisor, and may have erred in the advice it gave. How the others came to be selected is still unexplained. What is not in doubt is that one of the two panels only met on a single occasion, and the other only met twice before independently concluding that the conduct of the two
Stoke paediatricians merited immediate suspension. The reports show no evidence of their ever sounding out any other expert opinion, and we know they did not speak during this time to the clinicians whose work they were investigating, before "recommending that the Trust review [their] positions as employees," and asking for their reports to be sent to the General Medical Council (GMC), a statutory body with power to permanently ban doctors from clinical practice in the UK.

That the subsequent more deliberative investigations by two fresh and more carefully constituted panels should have exonerated Samuels and Southall from almost all criticism suggests that the conclusions of the earlier panels must have been deeply flawed. It is only the convention that those who undertake such inquiries should remain unnamed that now protects their reputation from similar damaging exposure.

In counting the cost of this whole sadly botched affair, the public needs to be brought to an appreciation of the extent to which this slow moving scandal has enveloped the entire UK paediatric profession. It has sapped its motivation to conduct clinical research, and sent young doctors a strong signal that, unless they want to risk a public pillorying, it is wise to avoid child protection work. Many nurses and doctors working in Stoke have been damaged by this mismanaged business. It addition, despite protestations to the contrary, the original Government inquiry was pivotal in triggering the other multiple inquiries later undertaken by the Trust. Those who launched that first inquiry without giving it giving it proper "rules of engagement" have a lot to answer for.

However, before finding fault in others, we need to look to see how we, ourselves, behave when asked to sit in judgement on our colleagues. Our College needs to find more transparent ways of recommending possible members of inquiry panels (a move that is already well in hand). Perhaps we should draft some rules of engagement if collaboration with other medical colleges (including those of Nursing and Midwifery) does not come up with common guidelines. The guaranteed anonymity of panels means that there is always a risk that slipshod behaviour could go undetected. Even malicious or vindictive behaviour could, in theory, go unchecked. Can that be allowed to continue?

And should we rest content even if it is all over now bar the shouting? What about that shouting? There are seven families 
who still feel angry that, two years after they said their CNEP study consent forms had been forged, ${ }^{14}$ no independent body has yet addressed that claim. Those who supervised that study share that dissatisfaction, and the 34 once-junior doctors who took those consents also want their names cleared. The Government panel decided this was a matter of possible professional misconduct for the GMC to deal with, ${ }^{12}$ but the GMC (in its own inscrutable way) seems to have decided that it was, in the first instance, an employment matter for the Trust. The Trust took a view on these allegations two years ago $^{13}$ and nothing that has happened since has led it to change its mind, ${ }^{4}$ but the public has no way of knowing how thorough this investigation has been. The families, in frustration, have also lodged complaints with the police, but they (in their equally inscrutable way) seem to have decided that this is probably a civil or an employment issue, and not a criminal matter. ${ }^{15}$

Indeed, since the GMC seems to have left several complaints "on hold" until Trust inquiries were complete, it is not yet really all over bar the shouting. It took four years for the GMC to exonerate the Trust's Acting Chief Executive when he was accused of a breach of confidence after he was called on to counter the first public allegation of forgery in May 1997. ${ }^{16}$ Let us hope it does not take as long for the GMC to rule on the other cases. Justice delayed can be justice denied. It is, in addition, all too easy to smear someone in public by saying "they are under investigation by the GMC you know". ${ }^{17}$

This is, however, only the most extreme element of the most serious allegation to come out of the long sad saga at Stokethe assertion that consent to inclusion in a neonatal research study was not properly and diligently obtained. Perhaps the professions should demand and get a truly independent body - a National Panel for Research Integrity_which could look at such issues objectively and dispassionately in an open and public way. Several such calls have been made in the last few years, ${ }^{18}$ the latest by the Royal College of Physicians of Edinburgh. ${ }^{19} 20$ There are many outside the UK, who do not understand why the allegations were taken so seriously, why their investigation was allowed to drag on so long, and why so little was done to rebut the many distorted stories circulating in the media. ${ }^{21}$

It is important, however, not to become too introspective. The real scandal of what happened at Stoke is not what it did to two senior doctors, but the damage it risked doing to the flimsy net that society has constructed to protect vulnerable children from sustained cruelty over the last twenty yearscruelty that is sometimes so severe that it amounts to torture, and so criminal that it results in death.

\section{Key points}

- Inquiries need to be fairer, faster and more focused

- They also need to be more open to external scrutiny

- They are expensive. Any flawed preliminary review of the need for such a process inevitably results, therefore, in a serious misuse of public money

\section{Authors' affiliations}

E Hey, Retired Paediatrician, Newcastle upon Tyne, UK

P Fleming, Royal Hospital for Children, Bristol BS2 8BJ, UK

J Sibert, Department of Child Health, University of Wales College of Medicine, Llandough Hospital, Penarth CF64 IAZ, UK

Correspondence to: Dr Hey; shey@easynet.co.uk

\section{REFERENCES}

1 Marcovitch H. Diagnose and be damned. BM 1999;319:1376.

2 North Staffordshire Hospital NHS Trust. Press release, 9.12.99.

3 Ferriman A. Paediatrician to be reinstated. BM 2001:322:1085.

4 North Staffordshire Hospital NHS Trust. Press release, 12.10.01

5 "Dispatches" television programme "The Munchausen File" transmitted by Channel Four, 2.2.94

6 Southall DP, Plunkett MCB, Banks MW, et al. Covert video recordings of life-threatening child abuse: lessons for child protection. Pediatrics 1997; 100:735-60.

7 Hey E, Chalmers I. Investigating allegations of research misconduct: the vital need for due process. BM 2000;321:752-5 and 1348-9.

8 Anonymous. When a doctor is suspended so is family life. $B M$ 2001:322:683.

9 Lightfoot L. Police investigate child abuse expert. Sunday Times 1.1.95 (see also 5.2.95)

10 Blackhurst $\mathbf{D}$. The Griffiths report: chance remark led to quest for the truth. The Sentinel, 19.5.00.

11 Samuels MP, Raine J, Wright $T$, et al. Continuous negative extrathoracic pressure in neonatal respiratory failure. Pediatrics 1996;98: 1 154-60.

12 NHS Executive West Midlands Regional Office. Report of a review of the research framework in North Staffordshire Hospital NHS Trust (Griffiths report). Leeds: NHS Executive, 2000. (www.doh.gov.uk/wmro/ northstaffs.htm, updated 8 May 2000.)

13 North Staffordshire NHS Trust. Press release, 1.9.99

14 Blackhurst D. CNEP forgery probe widens. The Sentinel, 2.9.99

15 Blackhurst D. Let police lead baby test probe. The Sentinel, 6.8.01

16 Dyer C. Hospital chief was right to release patient consent forms to media. BM 2001;322:1266.

17 Campbell DA. Unfair and one-sided. GMC News 2001;4:6.

18 Lock S, Wells F, Farthing M, eds. Fraud and misconduct in medical research, 3rd edn. London: BM Books, 2001.

19 Stonier P, Lowe G, Mclnnes $G$, et al. A national panel for research integrity: a proposed blueprint for the prevention and investigation of misconduct in biomedical research. Proc R Coll Physicians Edinb 2001 (In press).

20 Smith R, Meeting calls for a national body to respond to research misconduct. BN 2001;323:889.

21 Lucey J. Abuse of people trying to protect children from abuse. Lancet 2001;358:1556. 